\title{
Biological variations, genetic polymorphisms and familial resemblance of TNF- $\alpha$ and IL-6 concentrations: STANISLAS cohort
}

\author{
Nadia Haddy ${ }^{1,2}$, Catherine Sass ${ }^{1,2}$, Sandy Maumus ${ }^{1,2}$, Bérangère Marie ${ }^{1,2}$, \\ Suzanne Droesch ${ }^{1,2}$, Gérard Siest ${ }^{1,2}$, Daniel Lambert ${ }^{1,2}$ and Sophie Visvikis ${ }^{*, 1,2}$
}

\author{
${ }^{1}$ INSERM U 525, 30 rue Lionnois, 54000 Nancy, France; ${ }^{2}$ Centre de Médecine Préventive, 2, avenue du Doyen Jacques \\ Parisot, 54500 Vandoeuvre-lès-Nancy, France
}

Cytokines are involved in the development of several inflammatory diseases and atherosclerosis. Their variations in healthy individuals are not well defined. The aims of this study were: firstly, to identify factors affecting biological variation of interleukin-6 (IL-6) and tumour necrosis factor-alpha (TNF- $\alpha$ ); secondly, to study their family resemblance; and thirdly, to evaluate the effect of two TNF- $\alpha(-308 \mathrm{G} / \mathrm{A}$ and $-238 \mathrm{G} / \mathrm{A})$ and two IL-6 polymorphisms (174G/C and $-572 \mathrm{G} / \mathrm{C}$ ) on their corresponding circulating levels. A total of 171 healthy families selected from the STANISLAS cohort were studied. Age was negatively related to TNF$\alpha$ concentrations in offspring only (both sons and daughters). Additionally, IL-6 and TNF- $\alpha$ levels were differently influenced by gender, white blood cells, tobacco consumption, and HDL-cholesterol level. A weak significant familial resemblance for TNF- $\alpha$ concentration was observed in siblings only. There was no significant familial resemblance for IL- 6 levels. The TNF- $\alpha-308 \mathrm{~A}$ allele was associated with decreased TNF$\alpha$ concentrations in both offspring aged less than 18 and males without overweight $\left(\mathrm{BMI}<25 \mathrm{~kg} / \mathrm{m}^{2}\right)$. Fathers carrying the IL-6 -174CC genotype had higher IL-6 levels than those with the IL-6 $-174 \mathrm{G}$ allele. Parents with the IL-6 -572GG genotype had higher IL-6 concentrations than the C allele carriers. In this sample of healthy families, plasma levels of IL- 6 and TNF- $\alpha$ were differently affected by biological parameters including age, gender and smoking, and the impact of their respective polymorphisms was influenced by gender, age and BMI.

European Journal of Human Genetics (2005) 13, 109-117. doi:10.1038/sj.ejhg.5201294

Published online 3 November 2004

Keywords: atherosclerosis; cytokines; genetic polymorphisms

\section{Introduction}

Chronic inflammatory process atherosclerosis plays an important role in both initiation and progression of coronary and peripheral artery atherosclerosis. ${ }^{1}$ The genesis of the atherosclerotic plaque depends on interaction of

*Correspondence: Dr S Visvikis, Unité INSERM 525, Faculte de Pharmacie, Centre du Médicament, Université Henri Poincaré Nancy 1, 30 rue Lionnois, Nancy, France. Tel: + 3338368 2184; Fax: + 3338332 1322; E-mail: Sophie.Visvikis@cmp.u-nancy.fr

Received 15 December 2003; revised 10 August 2004; accepted 19 August 2004 cellular components of the immune system such as cytokines and cell adhesion molecules, with lipids, platelets, and endothelial cells.

Tumour necrosis factor alpha (TNF- $\alpha$ ) is a proinflammatory cytokine, ${ }^{2,3}$ mainly produced by monocytes, macrophages, ${ }^{4}$ and by $\mathrm{T}$ and B lymphocytes. ${ }^{5,6}$ TNF- $\alpha$ plasma concentrations increase in patients affected with premature coronary artery disease ${ }^{7}$ and is involved in obesity and insulin resistance. ${ }^{8,9}$ Its expression is regulated at the transcriptional level. ${ }^{10}$ Recently, a polymorphism affecting TNF- $\alpha$ transcription has been identified in the promoter 
region of the gene, at nucleotide position $-308 .{ }^{11}$ Padovani et al $^{12}$ have shown that this polymorphism may increase the risk of myocardial infarction (MI) in obese subjects. Moreover, Collins et al ${ }^{13}$ have found a significant association between Alzheimer's disease (AD) and a haplotype that included the -308 polymorphism and the TNF- $\alpha-238 \mathrm{G} / \mathrm{A}$ polymorphism, in addition to a significant association involving solely the -238 polymorphism.

Interleukin-6 (IL-6) is a circulating cytokine secreted by activated macrophages and lymphocytes. ${ }^{14}$ Adipose tissue produces up to $30 \%$ of its total circulating concentration in healthy subjects. ${ }^{14,15}$ Circulating levels of IL-6 are elevated in coronary heart disease. ${ }^{16,17}$ Fishman et al, ${ }^{18}$ have identified a G/C polymorphism at nucleotide -174 within the promoter of IL- 6 gene that could modify its expression. This polymorphism may also contribute to the susceptibility to type I diabetes ${ }^{19,20}$ and lipid abnormality. ${ }^{21}$ Another potentially functional IL-6 polymorphism $(-572 \mathrm{G} / \mathrm{C})$ has been recently identified. ${ }^{22}$

Biological and genetic variations of TNF- $\alpha$ and IL- 6 have never been defined in a healthy family population including children. Therefore, the objective of this study realised in such a population was to identify the factors affecting biological variation of these two molecules, to study their familial resemblance, and also to search for associations between their gene polymorphisms and the expression of the corresponding proteins.

\section{Methods and materials}

\section{Subjects and data collection}

The studied population was a sample of the STANISLAS cohort, a longitudinal family study previously described, ${ }^{23}$ designed to investigate factors related to cardiovascular disease. Participants were Caucasian and came from the Vosges and the South of Meurthe-et-Moselle (Eastern part of France). The members of the 171 families selected were apparently in good health, not under lipid-lowering and/or cardiovascular drug treatment and free from known serious and/or chronic illnesses; no one demonstrated clinical, biochemical or haematological proof of cardiovascular, hepatic or renal failure. Each subject gave a written informed consent for participating in this study, which was approved by the Local Ethics Committee.

The data collection included measurements of basic blood constituents, physical examination and medical history. Information on drug intake (notably anti-inflammatory drugs, oral contraceptives), assessing smoking status and alcohol consumption, were obtained.

\section{Blood sample and analysis}

Blood samples were collected after an overnight fast, in the morning between 9 and $10 \mathrm{~h}$. Serum and plasma samples were separated by centrifugation at $2000 \mathrm{~g}$ for $15 \mathrm{~min}$. Serum cholesterol and triglyceride (TG) levels were mea- sured using standard enzymatic methods (Merck, Darmstadt, Germany) on an automated analyser AU5021 (Olympus, Japan), and serum HDL-C was assessed after precipitation of apolipoprotein B-containing particles by phosphotungstic acid- $\mathrm{MgCl}_{2}$ on a Cobas-Mira (Roche Diagnostic systems, France).

Blood samples for TNF- $\alpha$ and IL- 6 were treated within $2 \mathrm{~h}$ (centrifugation within $1 \mathrm{~h}$, and freezing (liquid nitrogen) within $2 \mathrm{~h}$ after blood was collected), and circulating plasma levels of IL- 6 and TNF- $\alpha$ were measured by a commercially available enzyme-linked immunosorbent assay (ELISA) (R\&D Systems, Abington, UK). The intraassay coefficient of IL- 6 and TNF- $\alpha$ variations was $7.0 \%$ and the inter-assay coefficients were 14.0 and $13.0 \%$ respectively. Body mass index (BMI) was calculated according to Quetelet's formula: weight $(\mathrm{kg}) /$ height $\left(\mathrm{m}^{2}\right)$. The genotyping of individuals for the TNF- $\alpha-308 \mathrm{G} / \mathrm{A}$, TNF- $\alpha-238 \mathrm{G} / \mathrm{A}$, IL-6 - 174 G/C and IL-6 -572 G/C polymorphisms was performed using a multiplex assay, as described previously. ${ }^{24}$

\section{Statistical analysis}

Data for IL-6, TNF- $\alpha$ and HDL-cholesterol were logtransformed before statistical analysis to reduce the skewness of the distributions. Statistical analysis was performed with SAS software (SAS Institute Inc., USA). As individuals within a family are not independent, statistical analyses were based on the generalised estimating equation (GEE) technique, $^{25}$ using the SAS GENMOD procedure with a repeated statement. Multiple regression analysis was used to determine factors of biological variation of TNF- $\alpha$ and IL6 concentrations in each group of relatives (fathers, mothers, sons and daughters). The following parameters have been tested as confounding variables: age, BMI, white blood cells, tobacco and alcohol consumption, antiinflammatory and contraceptive drug intake, and HDLcholesterol. Family correlations for TNF- $\alpha$ and IL- 6 concentrations were estimated by the GEE technique. ${ }^{26}$

Hardy-Weinberg equilibrium was tested for the studied polymorphisms by a chi-square test $\left(\chi^{2}\right)$. Linkage disequilibrium between pairs of loci was tested by the Arlequin software. Associations between TNF- $\alpha$ polymorphisms ( $-308 \mathrm{G} / \mathrm{A}$ and $-238 \mathrm{G} / \mathrm{A})$ and TNF- $\alpha$ circulating levels, and between IL-6 polymorphisms $(-572 \mathrm{G} / \mathrm{C}$ and $-174 \mathrm{G} /$ C) and IL-6 circulating levels were tested using the SAS GENMOD procedure. Due to the small number of individuals homozygous for the less frequent allele, homozygotes have been pooled with the corresponding heterozygotes for the statistical analysis. Statistical significance was set at $P<0.05$. For multiple correlations Bonferroni correction was applied and significance was set at $P \leqslant 0.01$. 


\section{Results}

General characteristics of the studied population are given in Table 1. IL-6 showed a strong and positive correlation with TNF- $\alpha$ (data not shown).

\section{Biological determinants of IL-6}

Factors of biological variation of IL- 6 concentration were gender, age, BMI, tobacco, white blood cells and HDLcholesterol concentration. In the overall population, sons had lower IL-6 concentrations than fathers $(P=0.01)$, whereas IL-6 concentrations were higher in daughters than in mothers $(P=0.046)$. Fathers had higher IL-6 concentrations than mothers, but no statistical difference was observed between sons and daughters (Table 1).

Figure 1a shows the variation of IL- 6 concentrations according to age. In offspring, IL-6 concentrations decreased significantly with age in both genders $(P=0.02)$. Over age 20 years old, IL-6 levels in offspring reached those of the youngest parents ( $\leqslant 45$ years). Then IL- 6 concentrations increased with age in parents $(P=0.025)$. These two statistical differences were obtained with monoparametric analysis. In a second step, independent determinants of IL6 plasma concentrations in parents and offspring were searched using a multiparametric analysis (Table 2). In this case, age was not found not to be a determinant. White blood cell (WBC) number was significantly associated with increased IL- 6 concentrations in sons $(P \leqslant 0.001)$. Tobacco consumption was significantly related to IL- 6 concentrations in fathers only $(P \leqslant 0.01)$. HDL-cholesterol concentration showed a significant negative relationship with IL-6 concentrations in daughters $(P \leqslant 0.01)$.

The main factor for IL- 6 variation was: tobacco in fathers $\left(R^{2}=9.1 \%\right)$, HDL-cholesterol in daughters $\left(R^{2}=4 \%\right)$ and $\mathrm{WBC}$ in sons $\left(R^{2}=8.7 \%\right)$.

\section{Biological determinants of TNF- $\alpha$}

Biological determinants of TNF- $\alpha$ concentration were tobacco in fathers, age in mothers and in children. TNF- $\alpha$ levels were significantly higher in offspring than in parents, $(P \leqslant 0.001$ in males and in females). No difference according to gender was observed (Table 1 ). Figure $1 \mathrm{~b}$ shows the variation of $\mathrm{TNF}-\alpha$ concentrations according to age. In offspring, TNF- $\alpha$ concentration decreased considerably (from 3.75 to 1.40$)$ with age $(P<0.001)$. In parents, no significant variation of TNF- $\alpha$ levels with age was observed. Independent determinants of TNF- $\alpha$ plasma concentrations in parents and offspring are presented in Table 3 . Tobacco consumption was significantly and negatively associated with TNF- $\alpha$ levels in fathers only $(P \leqslant 0.01)$. The total percentage of TNF- $\alpha$ variation explained by age in offspring was 3.8 and $6 \%$ in sons and daughters, respectively. In fathers, tobacco consumption explained $5.7 \%$ of the variability of TNF- $\alpha$ level.

Table 1 Characteristics of the population

\begin{tabular}{|c|c|c|c|c|c|c|}
\hline & Fathers $(N=171)$ & Mothers $(N=171)$ & $P$ & Sons $N=208$ & Daughters $N=199$ & $P$ \\
\hline Age (years) & $\begin{array}{c}44.7 \pm 3.9 \\
38-56\end{array}$ & $\begin{array}{c}43.0 \pm 4.0 \\
33-54\end{array}$ & $<0.001$ & $\begin{array}{c}16.0 \pm 3.9 \\
6-29\end{array}$ & $\begin{array}{l}15.9 \pm 3.8 \\
5-27\end{array}$ & 0.538 \\
\hline BMI $\left(\mathrm{kg} / \mathrm{m}^{2}\right)$ & $25.4 \pm 3.0$ & $24.1 \pm 4.2$ & 0.002 & $20.4 \pm 3.2$ & $20.5 \pm 3.2$ & 0.881 \\
\hline Smoking (cigarette/day) & $4.65 \pm 9.32$ & $2.20 \pm 6.27$ & 0.004 & $2.02 \pm 4.99$ & $1.25 \pm 3.88$ & 0.080 \\
\hline Alcohol consumption (g/day) & $20.6 \pm 24.7$ & $6.10 \pm 11.2$ & $<0.001$ & $1.79 \pm 6.16$ & $0.82 \pm 2.44$ & 0.036 \\
\hline White blood cells $\left(10^{9} / 1\right)$ & $6.65 \pm 1.77$ & $6.86 \pm 1.65$ & 0.296 & $6.56 \pm 1.70$ & $6.96 \pm 1.61$ & 0.014 \\
\hline Total cholesterol ( $\mathrm{mmol} / 1)$ & $5.89 \pm 1.00$ & $5.63 \pm 0.89$ & 0.009 & $4.33 \pm 0.74$ & $4.75 \pm 0.89$ & $<0.001$ \\
\hline Triglycerides $(\mathrm{mmol} / 1)^{\mathrm{a}}$ & $1.42 \pm 0.77$ & $1.04 \pm 0.58$ & $<0.001$ & $0.88 \pm 0.39$ & $0.91 \pm 0.45$ & 0.431 \\
\hline $\mathrm{HDL}$-cholesterol $(\mathrm{mmol} / 1)^{\mathrm{a}}$ & $1.47 \pm 0.44$ & $1.80 \pm 0.45$ & $<0.001$ & $1.42 \pm 0.34$ & $1.61 \pm 0.40$ & $<0.001$ \\
\hline Glucose $(\mathrm{mmol} / 1)$ & $5.09 \pm 0.53$ & $4.81 \pm 0.46$ & $<0.001$ & $4.77 \pm 0.47$ & $4.68 \pm 0.43$ & 0.041 \\
\hline $\begin{array}{l}\text { Pill \% } \\
\text { Anti-inflammatory drugs \% }\end{array}$ & $\overline{7.0}$ & $\begin{array}{l}20.5 \\
5.2\end{array}$ & & $\overline{0.5}$ & $\begin{array}{c}23.6 \\
5.0\end{array}$ & \\
\hline \multicolumn{7}{|l|}{$\operatorname{lL}-6(p g / m)^{a}$} \\
\hline Means $\pm S D$ & $1.53 \pm 2.04$ & $1.11 \pm 1.00$ & 0.039 & $1.24 \pm 1.60$ & $1.43 \pm 2.03$ & 0.590 \\
\hline Geometric means & $1 . \overline{0} 2$ & $0 . \overline{8} 6$ & & $0 . \overline{8} 2$ & $0 . \overline{8} 6$ & \\
\hline \multirow[t]{2}{*}{ Range } & $0.094-16.1$ & $0.094-7.23$ & $P=0.01$ & $0.094-12.7$ & $0.094-14.5$ & \\
\hline & & 1 & $P=0.046$ & & & \\
\hline \multicolumn{7}{|l|}{$T N F-\alpha(p g / m l)^{a}$} \\
\hline Means $\pm S D$ & $2.05 \pm 3.87$ & $2.57 \pm 4.49$ & 0.457 & $2.73 \pm 3.09$ & $3.44 \pm 4.07$ & 0.182 \\
\hline Geometric means & $0 . \overline{9} 3$ & 1.03 & & 1.66 & 1.92 & \\
\hline \multirow[t]{2}{*}{ Range } & $0.12-32.6$ & $0.12-26.0$ & & $0.12-19.3$ & $0.12-27.6$ & \\
\hline & 1 & & $\begin{array}{l}P \leq 0.001 \\
P \leq 0.001\end{array}$ & & & \\
\hline
\end{tabular}

Means \pm SD. $P$, difference according to gender.

${ }^{\text {a }}$ Statistical analysis realised from log values. 
Familial correlations for IL-6 and TNF- $\alpha$ concentrations

Familial correlations of TNF- $\alpha$ and IL- 6 are presented in Tables 4 and 5, respectively. A significant familial correlation of TNF- $\alpha$ levels was observed only between offspring $(\rho=0.182 \quad(0.07-0.29), \quad P<0.01) \quad$ (Table 4). The three
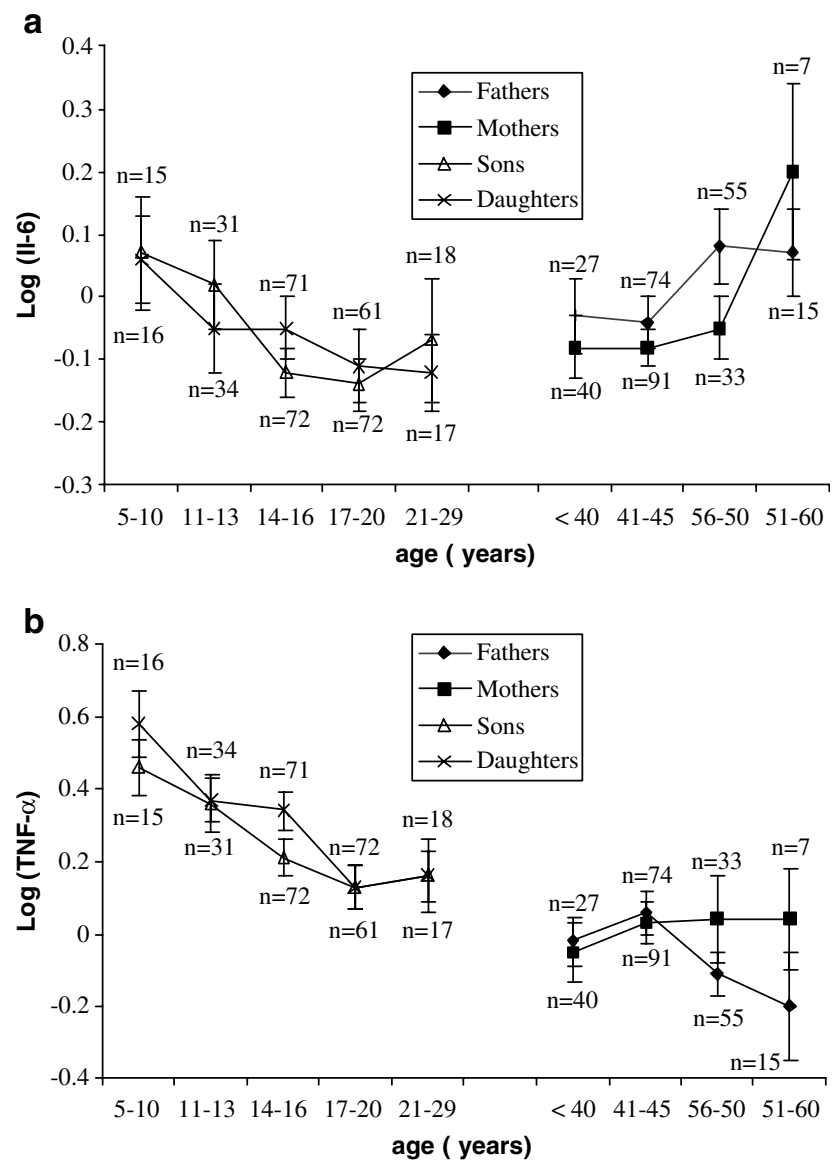

Figure 1 (a) Variation of IL-6 according to age and sex. Data are presented as the log of values + standard error. (b) Variation of TNF- $\alpha$ according to age and sex. Data are presented as the log of values + standard error. familial correlation coefficients were significantly different $\left(\chi^{2}=8.65\right.$ with $\left.2 \mathrm{df}, P<0.05\right)$. These results were not modified after adjustment for TNF- $\alpha$ covariates (Table 4 , model 2). No significant familial correlation was observed for IL- 6 concentration before and after adjustment for IL-6 covariates (Table 5).

\section{Relations between TNF- $\alpha$ polymorphisms and TNF- $\alpha$ concentration}

The $-308 \mathrm{G} / \mathrm{A}$ and $-238 \mathrm{G} / \mathrm{A}$ TNF- $\alpha$ genotype distributions did not differ from that expected by the Hardy-Weinberg equilibrium (Table 6). The frequency of the TNF- $\alpha-308 \mathrm{~A}$ allele was 0.104 and that of the TNF- $\alpha-238 \mathrm{~A}$ allele was 0.063. The two loci were in linkage disequilibrium $\left(\chi^{2}=5.59, P=0.018\right)$. In the overall population, individuals bearing the TNF- $\alpha-308 \mathrm{GG}$ genotypes tended to have higher TNF- $\alpha$ levels than carriers of the A allele $(P=0.06)$ (Table 7). In fact, the TNF- $\alpha-308$ G/A polymorphism was associated with decreased TNF- $\alpha$ concentrations in the offspring aged less than 18 years $(P=0.04)$. A significant interaction between the $-308 \mathrm{G} / \mathrm{A}$ TNF- $\alpha$ polymorphism and BMI was observed in males on TNF- $\alpha$ levels $(P=0.031$ after adjustment for covariates in each family relative). TNF- $\alpha$ decreased in males with BMI in individuals with the GG genotype $(\beta=-0.019 \pm 0.009, P<0.05)$, whereas no significant relationship was observed in the A allele carriers $(\beta=0.022 \pm 0.015, P<0.20)$. Consequently, the GG genotype was related to higher TNF- $\alpha$ levels in normal weight male subjects $\left(\mathrm{BMI}<25 \mathrm{~kg} / \mathrm{m}^{2}\right)(P=0.0045)$, whereas no significant effect was observed in overweight male subjects $\left(\mathrm{BMI} \geqslant 25 \mathrm{~kg} / \mathrm{m}^{2}\right)(P=0.27)$ (Table 8$)$. The $-308 \mathrm{G} / \mathrm{A}$ TNF- $\alpha$ polymorphism explained $3.5 \%$ of the TNF- $\alpha$ level in men whose BMI was below $25 \mathrm{~kg} / \mathrm{m}^{2}$.

\section{Relations between IL-6 polymorphisms and IL-6 concentration}

The IL-6 -572G/C and IL-6 - 174G/C genotypes distributions are presented in Table 6 . They did not differ from that expected by the Hardy-Weinberg equilibrium. The frequency of the $-572 \mathrm{C}$ allele was 0.053 and that of the $-174 \mathrm{C}$ allele was 0.395 . The two loci were in linkage disequilibrium $\left(\chi^{2}=24.97, P<0.001\right)$, the -572 CC geno-

Table 2 Determinants of circulating IL-6 concentrations in parents and offspring

\begin{tabular}{|c|c|c|c|c|c|c|c|c|}
\hline & \multicolumn{2}{|c|}{ Fathers } & \multicolumn{2}{|c|}{ Mothers } & \multicolumn{2}{|c|}{ Sons } & \multicolumn{2}{|c|}{ Daughters } \\
\hline & $\beta$ & $R^{2}$ & $\beta$ & $R^{2}$ & $\beta$ & $R^{2}$ & $\beta$ & $R^{2}$ \\
\hline Age & 0.013 & 2.2 & 0.013 & 2.7 & -0.015 & 2.4 & - & - \\
\hline BMI & 0.018 & 2.3 & 0.013 & 2.7 & - & - & - & 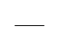 \\
\hline White blood cells & 0.029 & 1.6 & 0.034 & 2.9 & $0.065^{\star \star \star}$ & 8.7 & 0.036 & 1.9 \\
\hline Tobacco consumption & $0.009^{\star *}$ & 9.1 & - & - & - & - & - & \\
\hline HDL-cholesterol & - & - & -0.515 & 8.9 & - & - & $-0.717^{* *}$ & 4.0 \\
\hline
\end{tabular}

Data were obtained from log-transformed IL-6. After Bonferroni correction, only values of $P<0.01$ were considered to be significant. All other values are between 0.01 and 0.1 . They are considered not to be significant in this test. ${ }^{* \star} P \leqslant 0.01 ;{ }^{* \star \star} P \leqslant 0.001$. $\beta$ : estimated regression coefficient. 
Table 3 Determinants of circulating TNF- $\alpha$ concentrations in parents and offspring.

\begin{tabular}{lccccccc}
\hline & Fathers & \multicolumn{2}{c}{ Mothers } & & Sons & \multicolumn{2}{c}{ Daughters } \\
& $\beta$ & $R^{2}$ & $\beta$ & $R^{2}$ & $\beta$ & $R^{2}$ & $\beta$ \\
\hline Age & -0.019 & 2.0 & 0.006 & - & $-0.024^{* *}$ & 3.8 & $-0.032^{* * *}$ \\
BMl & - & - & 0.022 & 2.4 & - & - & - \\
Tobacco consumption & $-0.011^{* *}$ & 3.7 & - & - & - & - \\
\hline
\end{tabular}

Data were obtained from log-transformed TNF- $\alpha$. After Bonferroni correction, only values of $P<0.01$ were considered to be significant. All other values are between 0.01 and 0.1 . They are considered not to be significant in this test.

${ }^{* *} P \leqslant 0.01 ;{ }^{* *} P \leqslant 0.001$. $\beta$ : estimated regression coefficient.

Table 4 Familial correlations for TNF- $\alpha$ concentrations

\begin{tabular}{lcc}
\hline & Model 1 & Model 2 \\
\hline Parents/Parents & $0.056(-0.10-0.209)^{\mathrm{NS}}$ & $0.052(-0.106-0.207)^{\mathrm{NS}}$ \\
Parents/Offspring & $-0.039(-0.126-0.049)^{\mathrm{NS}}$ & $-0.034(-0.124-0.058)^{\mathrm{NS}}$ \\
Offspring/Offspring & $0.182(0.068-0.293)^{* *}$ & $0.215(0.095-0.328)^{* * *}$ \\
Heritability: $h^{2}$ & 0.22 & 0.25 \\
\hline
\end{tabular}

NS $=$ not significant, ${ }^{* *} P<0.01,{ }^{* * *} P<0.001$. Model $1:$ without adjustment; the three correlations were significantly different $\left(\chi^{2}=8.65\right.$ with $2 \mathrm{df}$ $P<0.05$ ). Model $2, \mathrm{TNF}-\alpha$ adjusted for age in all groups, $\mathrm{BMI}$ only in mothers, tobacco consumption in fathers; the three correlations were significantly different $\left(\chi^{2}=11.2\right.$ with $\left.2 \mathrm{df}, P<0.02\right)$

Table 5 Familial correlations for IL-6 concentrations

\begin{tabular}{lcc}
\hline & Model 1 & Model 2 \\
\hline Parents/Parents & $0.067(-0.076-0.205)^{\mathrm{NS}}$ & $0.024(-0.128-0.174)^{\mathrm{NS}}$ \\
Parents/Offspring & $0.057(-0.019-0.134)^{\mathrm{NS}}$ & $0.066(-0.002-0.134)^{\mathrm{NS}}$ \\
Offspring/Offspring & $0.067(-0.048-0.182)^{\mathrm{NS}}$ & $0.073(-0.049-0.194)^{\mathrm{NS}}$ \\
Heritability: $h^{2}$ & 0.12 & 0.14 \\
\hline
\end{tabular}

NS = not significant. Model 1: without adjustment. Model 2: log IL-6 values adjusted for white blood cells, age except in daughters, BMI in parents, tobacco consumption in fathers, HDL-cholesterol in mothers and daughters.

Table 6 TNF- $\alpha-308$ G/A, TNF- $\alpha-238 \mathrm{G} / \mathrm{A}$, IL-6 -174G/C and IL-6 -572G/C genotypes distributions

\begin{tabular}{lcccc}
\hline & Fathers $(\mathrm{n}=171)$ & Mothers $(\mathrm{n}=171)$ & Sons $(\mathrm{n}=208)$ & Daughters $(\mathrm{n}=199)$ \\
\hline TNF- $\alpha-308 \mathrm{G} / \mathrm{A}$ & & & & \\
GG & $127(74.27)$ & $146(85.38)$ & $173(83.17)$ & $158(79.40)$ \\
GA & $43(25.15)$ & $24(14.04)$ & $33(15.87)$ & $37(18.59)$ \\
AA & $1(0.58)$ & $1(0.58)$ & $2(0.96)$ & $4(2.01)$ \\
TNF- $\alpha-238 \mathrm{G} / \mathrm{A}$ & & & & \\
GG & $148(86.55)$ & $151(88.30)$ & $182(87.50)$ & $176(88.44)$ \\
GA & $22(12.87)$ & $19(11.11)$ & $25(12.2)$ & $22(11.06)$ \\
AA & $1(0.58)$ & $1(0.58)$ & $1(0.58)$ & $1(0.58)$ \\
IL-6-174 G/C & & & & \\
GG & $61(35.67)$ & $68(39.77)$ & $84(40.38)$ & $56(28.14)$ \\
GC & $81(47.37)$ & $75(43.86)$ & $93(44.71)$ & $114(57.29)$ \\
CC & $29(16.96)$ & $28(16.37)$ & $31(14.90)$ & $29(14.57)$ \\
IL-6-572 G/C & & & & \\
GG & $155(90.64)$ & $151(88.30)$ & $183(87.98)$ & $185(92.96)$ \\
GC & $16(9.36)$ & $20(11.70)$ & $25(12.02)$ & $14(7.04)$ \\
CC & $0(0)$ & $0(0)$ & $0(0)$ & $0(0)$ \\
\hline
\end{tabular}

Values are $n(\%)$. 
type being more frequently associated with the $-174 \mathrm{GG}$ genotype.

A relationship between IL-6 levels and $-174 \mathrm{G} / \mathrm{C}$ polymorphism was only observed in fathers $(P=0.018,1 \%$ of explained variation) and a relationship between IL-6 levels and $-572 \mathrm{G} / \mathrm{C}$ polymorphism was found in both parents ( $P=0.026,1.22 \%$ of explained variation) (Table 9$)$. Fathers with the $-174 \mathrm{CC}$ genotype had higher IL-6 levels than those with the $-174 \mathrm{G}$ allele and parents with the $-572 \mathrm{GG}$ genotype had higher IL- 6 concentrations than carriers of the $\mathrm{C}$ allele.

\section{Discussion}

Biological and genetic determinants of plasma TNF- $\alpha$ and IL-6 concentrations have been investigated in a healthy family-based population. Gender, age, tobacco consumption, BMI, WBC and HDL-C influenced differently IL- 6 and TNF- $\alpha$ concentrations. Contrary to TNF- $\alpha$, plasma IL- 6 levels were significantly different according to gender. However, previous studies did not find sex effect on IL-6. ${ }^{27}$

TNF- $\alpha$ concentrations decreased with age in both genders for offspring. After a multi-parameter analysis, age was shown to be a determinant of $\mathrm{TNF}-\alpha$ circulation level in offspring only (both sons and daughters). However, age was not a determinant of IL-6 level in any group (father,

Table 7 Association between -308 G/A TNF- $\alpha$ polymorphism and TNF- $\alpha$ circulating levels

\begin{tabular}{lccc}
\hline & $G G$ & $G A+A A$ & $P$ \\
\hline All subjects & $n=607$ & $n=145$ & \\
Log TNF- $\alpha$ & $0.146 \pm 0.021$ & $0.074 \pm 0.042$ & 0.06 \\
TNF- $\alpha$ geometric mean & 1.40 & 1.19 & \\
& & & \\
Parents & $n=273$ & $n=69$ & \\
Log TNF- $\alpha$ & $0.001 \pm 0.033$ & $-0.049 \pm 0.066$ & 0.49 \\
TNF- $\alpha$ geometric mean & 1.00 & 0.89 & \\
& & & \\
Offspring & $n=334$ & $n=76$ & \\
Log TNF- $\alpha$ & $0.268 \pm 0.026$ & $0.177 \pm 0.054$ & 0.13 \\
TNF- $\alpha$ geometric mean & 1.85 & 1.50 & \\
Offspring $\leqslant 18$ years & $n=254$ & $n=62$ & \\
Log TNF- $\alpha$ & $0.312 \pm 0.029$ & $0.183 \pm 0.059$ & 0.04 \\
TNF- $\alpha$ geometric mean & 2.05 & 1.52 & \\
\hline
\end{tabular}

Log TNF- $\alpha$ values are mean \pm standard error adjusted on age for all, tobacco for fathers and BMI for mothers. mother, sons or daughters). This is the first study on the variations of IL- 6 and TNF- $\alpha$ levels with age, including children and middle-aged subjects (from 5 to 56 years). An other study was realised with children only, aged from 3 to 17 years old, but no statistical analysis was performed. ${ }^{28}$ In the present study, a continuous decrease was observed in TNF- $\alpha$ between 5 and 17 years, whereas Sack et $a l^{28}$ found an increase in TNF- $\alpha$ level between 5 and 10 years and, and a decrease between 10 and 15 years. However, TNF- $\alpha$ concentrations were very high in some subjects (around $100 \mathrm{pg} / \mathrm{ml}$ ). In the literature, other studies concern populations aged from more than 15 years old. They also include adults in their statistics, and the effects of age are given by correlation coefficients in the entire population, without taking into account the effect of other parameters. In the present familial study, parents were studied independently of children. Moreover, not only coefficient of regression calculations but also multiparametric searches were done for determination of variations. Generally, other studies give an increase of IL-6 after adolescence. ${ }^{27,29-31}$ Few informations exist on the variation of TNF- $\alpha$. Values could increase in women. ${ }^{31}$ We only found variations in offspring. Metabolic pathways underlying the age-related variation in IL-6 are still under investigation. ${ }^{27}$ Effect of puberty and menopause have been checked in our study. No effect has been proved to be significant.

Smoking was associated with IL- 6 and TNF- $\alpha$ concentrations in fathers only. No relation was observed in mothers and offspring probably because of the modest tobacco

Table 9 Association between -572G/C, -174G/C IL-6 polymorphisms and IL-6 concentration

\begin{tabular}{lccc}
\hline IL-6 -572G/C & $G G(\mathrm{n}=306)$ & $G C+C C(\mathrm{n}=36)$ & $P$ \\
\hline $\begin{array}{l}\text { Parents } \\
\text { Log IL-6 }\end{array}$ & $-0.015 \pm 0.017$ & $-0.135 \pm 0.048$ & 0.026 \\
IL-6 geometric mean & 0.97 & 0.72 & \\
IL-6 -174G/C & $G G+G C(\mathrm{n}=142)$ & $C C(\mathrm{n}=29)$ & \\
\hline $\begin{array}{l}\text { Fathers } \\
\text { Log IL-6 }\end{array}$ & $-0.017 \pm 0.025$ & $0.140 \pm 0.075$ \\
IL-6 geometric mean & 0.96 & 1.38 & 0.018 \\
\hline
\end{tabular}

Log IL- 6 values are mean \pm standard error adjusted for age, white blood cells, age, BMI, tobacco consumption in fathers, HDLcholesterol in mothers.

Table 8 Association between $-308 \mathrm{G} / \mathrm{A}$ TNF- $\alpha$ polymorphism and TNF- $\alpha$ levels according to BMI in males

\begin{tabular}{|c|c|c|c|c|c|c|}
\hline & \multicolumn{2}{|c|}{$B M I<25 \mathrm{~kg} / \mathrm{m}^{2}$} & \multirow[t]{2}{*}{$P$} & \multicolumn{2}{|c|}{$B M I \geqslant 25 \mathrm{~kg} / \mathrm{m}^{2}$} & \multirow[t]{2}{*}{$\mathrm{P}$} \\
\hline & $G G(n=224)$ & $G A+A A(\mathrm{n}=59)$ & & $G G(\mathrm{n}=76)$ & $G A+A A(\mathrm{n}=20)$ & \\
\hline $\begin{array}{l}\text { Log TNF- } \alpha \\
\text { TNF- } \alpha \text { geometric mean }\end{array}$ & $\begin{array}{c}0.185 \pm 0.034 \\
1.53\end{array}$ & $\begin{array}{c}-0.010 \pm 0.056 \\
0.98\end{array}$ & 0.005 & $\begin{array}{c}-0.037 \pm 0.050 \\
0.92\end{array}$ & $\begin{array}{c}0.112 \pm 0.124 \\
1.29\end{array}$ & 0.27 \\
\hline
\end{tabular}

Log TNF- $\alpha$ values are mean \pm standard error adjusted on age for fathers and sons, tobacco for fathers. 
consumption. The fact that IL-6 was positively correlated to tobacco consumption is in agreement with previous studies. ${ }^{32,33}$ TNF- $\alpha$ and tobacco consumption were negatively related. Recent studies in healthy men showed that smoking status had no effect on TNF- $\alpha$ concentrations. ${ }^{32,34}$ Macrophage cells secrete more TNF- $\alpha$ in the presence of lower concentrations of smokeless tobacco than in the presence of higher concentrations. ${ }^{35}$ Vayssier et $a l^{36}$ also observed, as we did, that tobacco was related with decreased TNF- $\alpha$ concentrations, and concluded that it could abolish TNF- $\alpha$ cellular release.

BMI was not associated with IL-6 or TNF- $\alpha$. Numerous contradictory reports exist in the literature. ${ }^{27,37-39}$

Familial factors appear to have a modest impact on TNF$\alpha$ and IL-6 levels, as no significant familial correlation for IL- 6 and a small one were observed for TNF- $\alpha$ in offspring. However, genetic variants in TNF- $\alpha$ and IL- 6 genes could affect their respective gene product concentration with modulation by the context (ie gender, age and BMI).

IL- 6 and TNF- $\alpha$ familial resemblances are in contradiction with those of Pantsulaia et $a l^{27}$ who showed a strong familial resemblance especially for IL-6 (heritability about $80 \%$ ) and about $24 \%$ for TNF- $\alpha$. The only difference in methodology is that, in our study, plasma was stored in liquid nitrogen before analysis. In the Pantsulaia study, samples were kept frozen at $-80^{\circ} \mathrm{C}$ instead of liquid nitrogen. The discrepancy may be due to the different origins and ages of the two populations. This last population, aged from 18 to 75 years, was collected from small villages (Russian federation). The impact of genetic and/or environmental factors may be more important in such isolated populations.

The relationship between TNF- $\alpha-308 \mathrm{G} / \mathrm{A}$ polymorphism and TNF- $\alpha$ levels was dependent on age and BMI. The TNF$\alpha-308 \mathrm{~A}$ allele was related to decreased TNF- $\alpha$ levels in offspring (age $\leq 18$ years) and in normal-weight male subjects $\left(\mathrm{BMI}<25 \mathrm{~kg} / \mathrm{m}^{2}\right)$. Overweight may be not sufficient to produce a significant effect on the relation between the genotype and TNF- $\alpha$ levels, and to observe increased TNF- $\alpha$ levels with the A allele in overweight subjects. This is in agreement with the fact that obesity can induce an inappropriate secretion of IL- 6 and TNF- $\alpha .{ }^{40,41}$

No relation was observed between the TNF- $\alpha-238 \mathrm{G} / \mathrm{A}$ polymorphism and TNF- $\alpha$ level. Contradictory results may be found in the literature: both an increase ${ }^{41-43}$ and a decrease $^{44}$ in TNF- $\alpha$ protein expression can be associated with the $-238 \mathrm{~A}$ allele.

Men with the $-174 \mathrm{CC}$ genotype and adults with the -572GG genotype had higher IL-6 levels, the two genotypes being in linkage disequilibrium. This association between $-174 \mathrm{C}$ allele and higher levels of plasma IL-6 is supported by another study of patients with aneurysmal disease, where subjects with the $\mathrm{C}$ allele had higher IL-6 levels and higher mortality. ${ }^{45}$ However, Fishman et al ${ }^{18}$ found that the $\mathrm{C}$ allele was associated with lower IL- 6 levels in a small group of healthy men and women aged from 40 to 75 years old. The $-174 \mathrm{G} / \mathrm{C}$ polymorphism could exhibit different effects in individuals older than those included in the present study (men 38-56 years old). Our results are in agreement with Brull et al, ${ }^{46}$ who found the $\mathrm{C}$ allele related to increased IL-6 levels in patients after coronary artery bypass. Consistent with these findings, the $\mathrm{C}$ allele was associated positively with C-reactive protein (CRP), ${ }^{47,48}$ and IL- 6 was reported as the primary determinant of the hepatic production of CRP. ${ }^{49}$ In addition, the $\mathrm{C}$ allele was more common in men affected with MI than in controls ${ }^{50}$ and IL- 6 was found elevated in coronary heart disease patients. ${ }^{16,17}$

The newly identified $-572 \mathrm{G} / \mathrm{C}$ IL-6 polymorphism ${ }^{22}$ is still less studied than the $-174 \mathrm{G} / \mathrm{C}$ IL- 6 polymorphism. For the first time, in a healthy population, a relationship has been shown between this polymorphism and IL-6 levels, the adults with the $-572 \mathrm{GG}$ genotype having an increased IL- 6 level compared with the carriers of the $\mathrm{C}$ allele. Brull et $a l^{46}$ showed that the IL-6 $-572 \mathrm{C}$ allele was related to increased Il-6 levels in patients after coronary artery bypass, whereas Humphries et $a l^{51}$ found that the IL-6 $-572 \mathrm{G} / \mathrm{C}$ polymorphism was not associated with $\mathrm{CHD}$ risk in healthy men.

\section{Conclusion}

In conclusion, we have determined, for the first time, the main biological factors affecting IL- 6 and TNF- $\alpha$ concentrations in a healthy family population including children. We have also shown genetic influences on TNF- $\alpha$ and IL- 6 plasma concentrations involving environmental factors. Two of them are of particular interest as they could concern the risk of cardiovascular disease, although this is in debate. If this is confirmed, it could help in the prevention of this pathology.

\section{Acknowledgements}

We are grateful for the support and the scientific involvement of $S$ Cheng and H Erlich and A Silbergleit of Roche Molecular Systems Inc., Alameda, CA, USA. We thank Dr DA Tregouet for help in statistical analysis. We also thank the staff of the Centre de Médecine Preventive of Vandoeuvre-lès-Nancy (France) for their involvement in the recruitment of the STANISLAS cohort. We are indebted to the families of the STANISLAS Survey, who made this study possible. The STANISLAS cohort study is supported by the Caisse Nationale d'Assurance Maladies des Travailleurs Salariés (CNAM), the Institut National de la Santé et de la Recherche Médicale (INSERM), the Région Lorraine and by Roche Diagnostics, Randox and Dade Behring. This study was also supported by the IDS grant (INSERM $n^{\circ}$ 4DOOSE/1999).

\footnotetext{
References

1 Ross R: Atherosclerosis - an inflammatory disease. $N$ Engl J Med 1999; 340: $115-126$
} 
2 Vassalli P: The pathophysiology of tumor necrosis factors. Annu Rev Immunol 1992; 10: 411-452.

3 Beutler B: TNF, immunity and inflammatory disease: lessons of the past decade. J Investig Med 1995; 43: 227-235.

4 Beutler B, Cerami A: The biology of cachectin/TNF-a primary mediator of the host response. Annu Rev Immunol 1989; 7: $625-655$

5 Aggarwal BB: Comparative analysis of the structure and function of TNF-alpha and TNF-beta. Immunol Ser 1992; 56: 61-78.

6 Spriggs DR, Deutsch S, Kufe DW: Genomic structure, induction, and production of TNF-alpha. Immunol Ser 1992; 56: 3-34.

7 Jovinge S, Hamsten A, Tornvall P et al: Evidence for a role of tumor necrosis factor alpha in disturbances of triglyceride and glucose metabolism predisposing to coronary heart disease. Metabolism 1998; 47: 113-118.

8 Hotamisligil GS, Shargill NS, Spiegelman BM: Adipose expression of tumor necrosis factor-alpha: direct role in obesity-linked insulin resistance. Science 1993; 259: 87-91.

9 Hotamisligil GS, Spiegelman BM: Tumor necrosis factor alpha: a key component of the obesity-diabetes link. Diabetes 1994; 43: $1271-1278$.

10 Raabe T, Bukrinsky M, Currie RA: Relative contribution of transcription and translation to the induction of tumor necrosis factor-alpha by lipopolysaccharide. I Biol Chem 1998; 273: 974-980.

11 Wilson AG, Symons JA, McDowell TL, McDevitt HO, Duff GW: Effects of a polymorphism in the human tumor necrosis factor alpha promoter on transcriptional activation. Proc Natl Acad Sci USA 1997; 94: 3195-3199.

12 Padovani JC, Pazin-Filho A, Simoes MV, Marin-Neto JA, Zago MA, Franco RF: Gene polymorphisms in the TNF locus and the risk of myocardial infarction. Thromb Res 2000; 100: 263-269.

13 Collins JS, Perry RT, Watson Jr B et al: Association of a haplotype for tumor necrosis factor in siblings with late-onset Alzheimer disease: the NIMH Alzheimer Disease Genetics Initiative. Am J Med Genet 2000; 96: 823-830.

14 Yudkin JS, Kumari M, Humphries SE, Mohamed-Ali V: Inflammation, obesity, stress and coronary heart disease: is interleukin-6 the link? Atherosclerosis 1999; 148: 209-214.

15 Mohamed-Ali V, Goodrick S, Rawesh A et al: Subcutaneous adipose tissue releases interleukin-6, but not tumor necrosis factor-alpha, in vivo. J Clin Endocrinol Metab 1997; 82: 4196-4200.

16 Rifai $\mathrm{N}$, Joubran $\mathrm{R}, \mathrm{Yu} \mathrm{H}$, Asmi M, Jouma M: Inflammatory markers in men with angiographically documented coronary heart disease. Clin Chem 1999; 45: 1967-1973.

17 Mendall MA, Patel P, Asante M et al: Relation of serum cytokine concentrations to cardiovascular risk factors and coronary heart disease. Heart 1997; 78: 273-277.

18 Fishman D, Faulds G, Jeffery R et al: The effect of novel polymorphisms in the interleukin-6 (IL-6) gene on IL-6 transcription and plasma IL-6 levels, and an association with systemic-onset juvenile chronic arthritis. J Clin Invest 1998; 102: $1369-1376$.

19 Fernandez-Real JM, Broch M, Vendrell J et al: Interleukin-6 gene polymorphism and insulin sensitivity. Diabetes 2000; 49: $517-520$.

20 Jahromi MM, Millward BA, Demaine AG: A polymorphism in the promoter region of the gene for interleukin- 6 is associated with susceptibility to type 1 diabetes mellitus. J Interferon Cytokine Res 2000; 20: $885-888$.

21 Fernandez-Real JM, Broch M, Vendrell J, Richart C, Ricart W: Interleukin-6 gene polymorphism and lipid abnormalities in healthy subjects. J Clin Endocrinol Metab 2000; 85: 1334-1339.

22 Terry CF, Loukaci V, Green FR: Cooperative influence of genetic polymorphisms on interleukin 6 transcriptional regulation. J Biol Chem 2000; 275: 18138-18144.

23 Siest G, Visvikis S, Herbeth B et al: Objectives, design and recruitment of a familial and longitudinal cohort for studying gene-environment interactions in the field of cardiovascular risk: the Stanislas cohort. Clin Chem Lab Med 1998; 36: 35-42.
24 Cheng S, Pallaud C, Grow MA et al: A multilocus genotyping assay for cardiovascular disease. Clin Chem Lab Med 1998; 36: $561-566$.

25 Liang KY, Zeger SL: Longitudinal data analysis using generalized linear models. Biometrika 1986; 73: 13-22.

26 Tregouet DA, Tiret L: Applications of the estimating equations theory to genetic epidemiology: a review. Ann Hum Genet 2000; 64: $1-14$.

27 Pantsulaia Ia, Trofimov S, Kobyliansky E, Livshits G: Genetic and environmental influences on IL-6 and TNF-alpha plasma levels in apparently healthy general population. Cytokine 2002; 19: 138-146.

28 Sack U, Burkhardt U, Borte M, Schadlich H, Berg K, Emmrich F: Age-dependent levels of select immunological mediators in sera of healthy children. Clin Diagn Lab Immunol 1998; 5: 28-32.

29 McKane WR, Khosla S, Peterson JM, Egan K, Riggs BL: Circulating levels of cytokines that modulate bone resorption: effects of age and menopause in women. J Bone Miner Res 1994; 9: 1313-1318.

30 Straub RH, Konecna L, Hrach S et al: Serum dehydroepiandrosterone (DHEA) and DHEA sulfate are negatively correlated with serum interleukin-6 (IL-6), and DHEA inhibits IL-6 secretion from mononuclear cells in man in vitro: possible link between endocrinosenescence and immunosenescence. $J$ Clin Endocrinol Metab 1998; 83: 2012-2017.

31 Mysliwska J, Bryl E, Foerster J, Mysliwski A: Increase of interleukin 6 and decrease of interleukin 2 production during the ageing process are influenced by the health status. Mech Ageing Dev 1998; 100: 313-328.

32 de Maat MP, Kluft C: The association between inflammation markers, coronary artery disease and smoking. Vascul Pharmacol 2002; 39: 137-139.

33 Bermudez EA, Rifai N, Buring JE, Manson JE, Ridker PM: Relation between markers of systemic vascular inflammation and smoking in women. Am J Cardiol 2002; 89: 1117-1119.

34 Skoog T, Dichtl W, Boquist S et al: Plasma tumour necrosis factoralpha and early carotid atherosclerosis in healthy middle-aged men. Eur Heart J 2002; 23: 376-383.

35 Seyedroudbari SA, Khan MM: In vitro effects of smokeless tobacco extract on tumor necrosis factor-alpha (TNF-alpha) and interleukin-1beta (IL-1beta) production, and on lymphocyte proliferation. Toxicon 1998; 36: 631-637.

36 Vayssier M, Favatier F, Pinot F, Bachelet M, Polla BS: Tobacco smoke induces coordinate activation of HSF and inhibition of NF$\kappa$ in human monocytes: effects on TNF alpha release. Biochem Biophys Res Commun 1998; 252: 249-256.

37 Kania D, Binkley N, Checovich M, Havighurst T, Schilling M, Erschler W: Elevated plasma levels interleukin-6 in postmenopausal women do not correlate with bone density. J Am Geriatr Soc 1995; 43: 236-239.

38 Scheidt-nave C, Bismar H, Leidig-Bruckner $\mathrm{G}$ et al: Serum interleukin 6 is a major predictor of bone loss in women specific to the first decade past menaupose. J Clin Endocrine Metab 2001; 5: 2032-2042.

39 Abrahamsen B, Bonnevie-Nielsen V, Ebbesen EN, Gram J, BeckNielsen H: Cytokines and bone loss in a 5-year longitudinal study-hormone replacement therapy suppresses serum soluble interleukine receptor and increases interleukine-1-receptor antagonist: The Danish Osteoporosis Prevention Study. J Bone Miner Res 2000; 15: 1545-1554.

40 Kern PA, Saghizadeh M, Ong JM, Bosch RJ, Deem R, Simsolo RB The expression of tumor necrosis factor in human adipose tissue. Regulation by obesity, weight loss, and relationship to lipoprotein lipase. J Clin Invest 1995; 95: 2111-2119.

41 Ziccardi P, Nappo F, Giugliano G et al: Reduction of inflammatory cytokine concentrations and improvement of endothelial functions in obese women after weight loss over one year. Circulation 2002; 105: 804-809.

42 Bayley JP, de Rooij H, van den Elsen PJ, Huizinga TW, Verweij CL: Functional analysis of linker-scan mutants spanning the -376 , $-308,-244$, and -238 polymorphic sites of the TNF-alpha promote. Cytokine 2001; 14: 316-323. 
43 Grove J, Daly AK, Bassendine MF, Day CP: Association of a tumor necrosis factor promoter polymorphism with susceptibility to alcoholic steatohepatitis. Hepatology 1997; 26: 143-146.

44 Kaluza W, Reuss E, Grossmann S et al: Different transcriptional activity and in vitro TNF-alpha production in psoriasis patients carrying the TNF-alpha 238A promoter polymorphism. J Invest Dermatol 2000; 114: 1180-1183.

45 Jones KG, Brull DJ, Brown LC et al: Interleukin-6 (IL-6) and the prognosis of abdominal aortic aneurysms. Circulation 2001; 103: $2260-2265$.

46 Brull DJ, Montgomery HE, Sanders J et al: Interleukin-6 gene $-174 \mathrm{~g}>\mathrm{c}$ and $-572 \mathrm{~g}>\mathrm{c}$ promoter polymorphisms are strong predictors of plasma interleukin-6 levels after coronary artery bypass surgery. Arterioscler Thromb Vasc Biol 2001; 21: 1458-1463.

47 Jenny NS, Tracy RP, Ogg MS et al: In the elderly, interleukin-6 plasma levels and the $-174 \mathrm{G}>\mathrm{C}$ polymorphism are associated with the development of cardiovascular disease. Arterioscler Thromb Vasc Biol 2002; 22: 2066-2071.

48 Vickers MA, Green FR, Terry C et al: Genotype at a promoter polymorphism of the interleukin-6 gene is associated with baseline levels of plasma C-reactive protein. Cardiovasc Res 2002; 53: 1029-1034.

49 Heinrich PC, Castell JV, Andus T: Interleukin-6 and the acute phase response. Biochem J 1990; 265: 621-636.

50 Georges JL, Loukaci V, Poirier $\mathrm{O}$ et al: Interleukin-6 gene polymorphisms and susceptibility to myocardial infarction: the ECTIM study. Etude Cas-Temoin de l'Infarctus du Myocarde. J Mol Med 2001; 79: 300-305.

51 Humphries SE, Luong LA, Ogg MS, Hawe E, Miller GJ: The interleukin-6 -174 G/C promoter polymorphism is associated with risk of coronary heart disease and systolic blood pressure in healthy men. Eur Heart J 2001; 22: 2243-2252. 